\title{
Approach coping dan belanja kompulsif pakaian dengan program studi sebagai variabel moderator
}

\author{
Djudiyah
}

Fakultas Psikologi, Universitas Muhammadiyah Malang, Indonesia

\begin{tabular}{l}
\hline Info Artikel \\
\hline Sejarah Artikel: \\
Diterima \\
I0 September 2020 \\
Direview \\
I5 September 2020 \\
Disetujui \\
30 September 2020 \\
Dipublikasikan \\
30 September 2020 \\
\hline Keywords: \\
Approach coping, \\
Compulsive buying, \\
Departement, \\
Female students
\end{tabular}

\begin{abstract}
Abstrak
Objektif: Pandemi Covid 19 yang mewabah di seluruh dunia saat ini berdampak pada cara individu dalam melakukan berbagai macam aktivitas, salah satunya dalam melakukan pembelanjaan. Mahasiswi dengan approach coping tinggi cenderung rasional dalam berbelanja sehingga mereka memiliki kecenderungan rendah untuk melakukan belanja kompulsif pakaian. Apalagi bila mereka sedang menempuh studi pada fakultas eksakta, yang cenderung banyak menggunakan analisa sintesa dalam proses pembelajaran. Penelitian ini bertujuan untuk mengetahui hubungan approach coping dengan belanja kompulsif pakaian pada mahasiswa dengan fakultas eksakta dan non eksakta sebagai variabel moderator.
\end{abstract}

Metode: Penelitian ini menggunakan pendekatan kuantitatif korelasional. Subjek penelitian ini berjumlah 264 mahasiswi aktif Universitas Muhammadiyah Malang. Metode pengumpul data yang digunakan adalah skala Coping Respon Inventoty (CRI) dan skala belanja kompulsif pakaian. Analisis data dilakukan dengan metode analisis moderasi (Moderation Analysis) dari Hyes dengan bantuan program SPSS versi 21 .

Temuan: Hasil analisis menunjukkan ada hubungan negatif antara approach coping an belanja kompulsif pakaian pada mahasiswi. Program studi mampu memoderasi hubungan antara approach coping dengan belanja kompulsif pakaian pada mahasiswi.

Kesimpulan: Hipotesis penelitian diterima

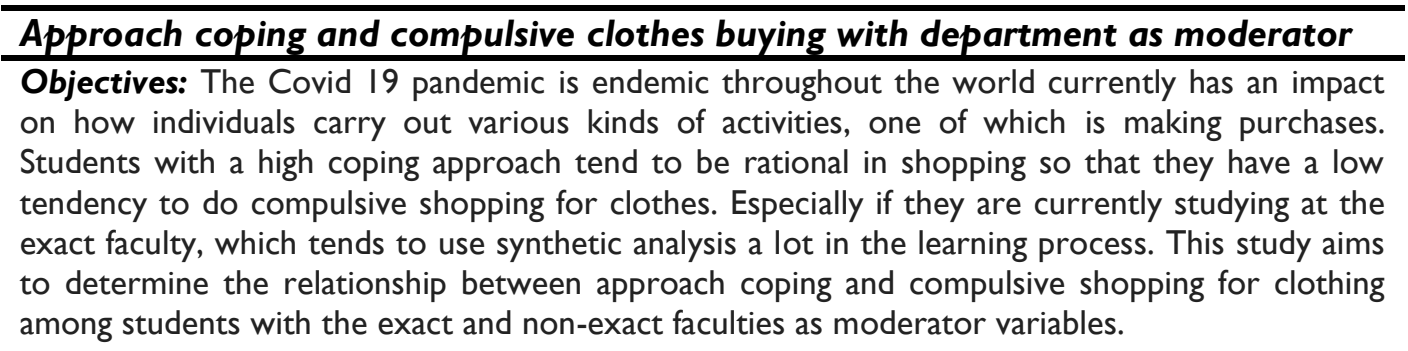

Method: This research used a correlational quantitative approach. The research subjects were 264 active students at the University of Muhammadiyah Malang. The data collection method used was the Coping Response Inventory scale (CRI) and the compulsive shopping scale for clothes. Data analysis was performed using the Moderation Analysis method of Hyes with the help of the SPSS version 21 program.

Findings: The analysis showed that there was a negative relationship between approach coping and compulsive shopping for clothes among female students. The study program was able to moderate the relationship between approach coping and compulsive shopping for clothes among female students.

Conclusions: Research hypothesis is accepted,

\footnotetext{
*Alamat korespondensi:

Universitas Muhammadiyah Malang

Jl. Raya Tlogomas No.246 Malang Jawa Timur 65।44

djudiyah@umm.ac.id
} 


\section{Pendahuluan}

Perkembangan teknologi informasi yang pesat saat ini berpengaruh pada semua aktivitas kehidupan, terutama pada perilaku konsumen. Konsumen dapat mengakses dengan mudah informasi tentang produk atau jasa yang dibutuhkan melalui media sosial. Riset Günüç dan Keskin (2016) pada 105 mahasiswa dan riset yang dilakukan Flórez, Escobar, Restrepo, Botero dan Arias (2017) pada 224 mahasiswa menemukan bahwa berkembangnya sosial media (internet) membuat konsumen mudah mendapatkan informasi tentang produk atau jasa yang dibutuhkan, mampu membanding-bandingkan harga, menghemat waktu, kemudahan akses, mencari hiburan, promosi/iklan berbagai produk dan jasa. Kemudahan akses informasi maupun untuk mendapatkan produk melalui toko online dapat mendorong orang untuk mengambil keputusan berbelanja secara impulsif dan pada akhirnya mengarahkan pada pembelanjaan kompulsif.

Riset O'Reilly (2016) menemukan bahwa jejaring sosial dapat menyebabkan perilaku kompulsif. Anak-anak muda yang berusia 18-30 tahun lebih banyak mengakses media sosial dan berperilaku lebih kompulsif dibanding dengan individu yang berusia 31-64 tahun. Banyaknya informasi tentang produk dan jasa secara online di media sosial yang mudah diakses, membuat konsumen mendapatkan banyak informasi tentang produk. Riset Filomensky dan Tavares (2009) menemukan bahwa belanja kompulsif terjadi karena adanya distorsi kognitif. Belanja kompulsif terjadi karena individu kurang mampu memproses informasi yang tidak relevan yang utama yang membentuk symptom sehingga tetap memelihara perilaku untuk melakukan pembelanjaan secara kompulsif. Dengan demikian, belanja kompulsif juga dipengaruhi oleh persepsi atau penilaian yang salah terhadap keputusan pembelanjaan yang dilakukan.

Riset Dziurzyńska, Pawłowska, dan Potembska, (2016) pada 408 mahasiswa yang berusia 19-28 tahun menemukan bahwa mahasiswa yang menggunakan avoidance coping tinggi cenderung adiksi mobile phone. Ha ini didukung oleh penelitian Djudiyah (2018) yang menemukan bahwa ada hubungan positif antara avoidance coping dengan belanja kompulsif pakaian. Hal ini menunjukkan bahwa semakin tinggi avoidance coping yang digunakan oleh individu maka mereka cenderung melakukan pembelanjaan kompulsif pakaian. Namun bagaimana hubungan antara approach coping dengan belanja kompusif pakaian penting untuk dibuktikan secara empiris.

Individu yang menggunakan strategi approach coping cenderung mengatasi permasalahan dengan cara yang lebih konstruktif. Mereka berusaha berpikir positif terhadap peristiwa yang terjadi pada dirinya, berusaha melakukan elaborasi terhadap cara-cara mengatasi permasalahan dan memilih satu alternative pemecahan persoalan yang menurutnya paling efektif untuk memecahkan permasalahan. Mereka mencoba mengaplikasikan alternative pemecahan permasalahan secara aktual. Ketika alternative pemecahan permasalahan tidak mampu mengatasi permasalahn, mereka akan mengevaluasinya kembali, menetapkan satu solusi yang dianggap efektif sampai diperoleh solusi (Buku modifikasi perilaku).

Penelitian Aghdar (2016) dan Servidio, Gentile dan Boca (2018) pada mahasiswa menemukan bahwa strategi coping yang digunakan mahasiswa berpengaruh terhadap kecenderungan adiksi. Mahasiswa yang menggunakan strategi coping yang efektif/adaptif memiliki kecenderungan rendah untuk adiksi dan sebaliknya. Riset yang dilakukan Otero-Lopes, dan Villardefracos (20l4) menemukan bahwa individu yang memiliki kecenderungan approach coping rendah dalam menghadapi persoalan kehidupan memiliki kerentanan terhadap perilaku adiksi khususnya adiksi dalam berbelanja. Ketika dihadapkan pada persoalan mereka cenderung banyak menggunakan aktivitas berpikir dalam kehidupannya termasuk berbelanja. Banyaknya informasi tentang produk dan jasa yang ditayangkan iklan di berbagai media cetak maupun elektronik, informasi atau harapan peer group, sales person, reviuwer pembeli dapat membuat mereka lebih selektif dalam memutuskan pembelanjaan. Dengan demikian, individu dengan kecenderungan approach coping tinggi cenderung melakukan pembelanjaan kompulsif rendah.

Mahasiswa dari program studi eksakta lebih banyak dihadapkan pada materi dan tugas-tugas perkuliahan yang memerlukan proses berpikir analisa sintesa, proses berpikir logis, bahkan berpikir lebih kompleks dan lebih praktis dibanding dengan mahasiswa non eksakta. Proses belajar ini akan berdampak pada perilaku seharihari, khususnya dalam berbelanja. Riset Udo-Imeh (2015) menemukan bahwa department (program studi) mampu memoderasi pengaruh kepribadian dengan perilaku berbelanja pada mahasiswa. Penelitian ini ingin membuktikan secara empiris program studi memoderasi pengaruh approach coping terhadap belanja kompulsif pakaian pada mahasiswi.

Belanja kompulsif yang sudah terdampak pada anak-anak muda akan berpengaruh pada pencapaian studi mereka. Riset yang dilakukan Benson, Dittmar dan Wolfsohn (20l0) menemukan bahwa anak-anak muda yang suka belanja kompulsif memiliki banyak pekerjaan untuk mendapatkan uang guna menopang gaya 
hidupnya yang cenderung suka berbelanja dan cenderung bekerja sepanjang waktu. Sebagai akibatnya mereka malas datang kuliah, malas mengerjakan tugas-tugas yang diberikan dosen. Mereka lebih berorientasi pada tujuan hidup jangka pendek dibanding dengan jangka panjang. Oleh karena itu, bila belanja kompulsif ini tidak dicarikan solusi akan berdampak pada studi mahasiswa.

Tiap-tiap orang memiliki kemampuan berbeda-beda dalam mengatasi persoalan hidup sehari-hari yang dialami. Individu yang memiliki keterampilan coping aktif akan cenderung memiliki perilaku adaptif yang lebih tinggi dibanding individu yang memiliki keterampilan coping aktif yang rendah. Coping dan perilaku adaptif merupakan strategi kognitif dan perilaku yang digunakan untuk memediasi tuntutan lingkungan internal maupun eksternal yang spesifik. Individu yang cenderung menggunakan approach coping, berusaha aktif untuk memediasi stress atau kecemasan baik secara kognitif maupun behavioral. Individu yang berusaha untuk memecahkan problem yang dialami dan berpikir positif akan menghasilkan outcome yang lebih positif dibanding yang berusaha untuk menggunakan coping menghindar (avoiding coping) dari persoalan yang dialami (Gupta, Derevensky \& Marget, 2004).

Individu yang memiliki keterampilan coping yang efektif atau approach coping cenderung mampu mengelola tuntutan situasional dengan baik memiliki sedikit kerentanan melakukan perilaku adiktif (Gupta, Derevensky \& Marget, 2004).. Skill coping yang adaptif mampu memproteksi untuk terjatuh pada pola-pola perilaku adiktif, salah satunya berbelanja kompulsif. Anak-anak muda yang cenderung melakukan pembelanjaan secara kompulsif pakaian, lebih dimotivasi oleh keinginan mereka untuk melakukan improve penampilan fisik mereka, merubah identitas, mendekati citra diri yang ideal, dan selalu mencoba untuk menyerupai orang lain (Ureta, 2007).

Individu yang suka melakukan pembelanjaan kompulsif tinggi cenderung memiliki pikiran yang distorsi atau memiliki pikiran yang irrasional dalam mengambil keputusan berbelanja. Berbelanja pakaian dilakukan sebagai cara untuk mengatasi emosi negatif yang dialami, berbelanja sebagai cara membangun identitas, dll. Pemikiran-pemikiran yang irrasional ini aktif ketika individu melakukan pembelanjaaan atau shopping (Filomensky \& Tavares, 2009; Kellett, \& Bolton, 2009) khususnya berbelanja pakaian. Isi pikiran yang irrasional ini akan mendorong individu untuk melakukan pembelanjaan terus menerus karena individu mendapatkan reinforcement positif dari dirinya sendiri maupun orang lain.

Individu yang cenderung menggunakan approach coping dalam kehidupan sehari-harinya akan mencoba memahami dan menganalisis informasi yang ada. Mereka mencoba berpikir positif terhadap kejadian-kejadian yang dialaminya serta berusaha mencari upaya pemecahannya (Moos, 2004). Cara pendekatan individu terhadap persoalan kehidupan yang cenderung bersifat rasional ini akan berpengaruh pada proses pencarian informasi, pemahaman terhadap informasi tentang produk atau jasa. Individu akan mempertimbangkan beberapa hal sebelum memutuskan untuk melakukan pembelanjaan (Schiffman, Kanuk, \& Wisenblit (20I0).

Individu yang menempuh studi pada program studi eksakta lebih banyak dihadapkan pada tugas-tugas yang memerlukan kemampuan memahami, menganalisa, berpikir kritis dan praktis di banding program studi non eksakta (Udo-Imeh, 20I5). Habit yang ada pada kehidupan perkuliahan semacam ini juga akan terbawa pada aktivitas-aktivitas kehidupan yang lain, khususnya dalam berbelanja. Individu yang sedang studi pada program studi eksakta akan berusaha mengidentifikasi kebutuhan dirinya akan pakaian, mempertimbangkan, dan mengambil keputusan yang lebih rasional untuk membeli atau tidak membeli pakaian yang ditawarkan oleh toko online maupun toko konvensional atau pengaruh dari teman dibanding dengan individu yang sedang studi di program studi non eksakta. Dengan demikian, program studi eksakta maupun non eksakta diduga mampu memperkuat hubungan antara approach coping dengan belanja kompulsif pakaian.

Berdasarkan uraian di atas dapat disimpulkan bahwa coping berpengaruh terhadap belanja kompulsif pakaian. Individu dengan approach coping tinggi cenderung melakukan pembelanjaan kompulsif pakaian rendah. Program studi dimana mahasiswa kuliah memoderasi hubungan antara approach coping dengan belanja kompulsif pakaian. Tujuan penelitian ini adalah untuk mengetahui pengaruh approach coping terhadap belanja kompulsif pakaian serta ingin mendapatkan bukti secara empiris peran program studi dalam memoderasi pengaruh approach coping terhadap belanja kompulsif pakaian. Hasil penelitian ini dapat digunakan sebagai bahan pertimbangan melakukan upaya prevensi untuk meminimalisir belanja kompulsif pakaian pada mahasiswa. 


\section{Metode}

Penelitian ini merupakan penelitian kuantitatif korelasional. Penelitian kuantitatif merupakan penelitian yang mengahasilkan skor yang berwujud angka. Penelitian korelasional adalah penelitian yang berusaha untuk mengetahui hubungan antara variabel bebas (approach coping) dengan variabel dependent (belanja kompulsif pakaian) (Suryabrata, 20I2).

Populasi pada penelitian ini adalah mahasiswi Universitas Muhammadiyah Malang. Sedangkan sampel pada penelitian ini berjumlah 246 mahasiswi yang diambil dengan teknik Proporsional Sampling. Ada I32 mahasiswa dari program studi eksakta dan II4 mahasiswa dari program studi non eksakta. Pengambilan data dilakukan di Kampus 2 Universitas Muhammadiyah Malang (Fakultas Kedokteran dan Farmasi) dan di Kampus 3 Universitas Muhammadiyah Malang (Fakultas Pertanian dan Peternakan, Fakultas Hukum, FISIP dan Fakultas Psikologi). Penelitian dilakukan pada bulan April 2019.

Variabel bebas dalam penelitian ini adalah approach coping, dan variabel tergantung pada penelitian ini adalah belanja kompulsif pakaian. Program studi eksakta dan non-eksakta sebagai variabel moderator. Approach coping merupakan respon yang diberikan anak-anak muda dalam menghadapi stressor/persoalan kehidupan. Anak-anak muda berupaya menganalisis persoalan yang dialami secara logis dan berpikir positif terhadap persoalan kehidupan, mencari petunjuk dan support untuk melakukan problem solving. Dengan demikian, anak-anak muda menggunakan pemikiran logis dalam menghadapi dan memecahkan persoalan kehidupan.

Belanja kompulsif pakaian adalah belanja pakaian yang dilakukan terus menerus karena adanya dorongan yang sangat kuat yang sulit dikendalikan. Belanja dilakukan untuk mereduksi emosi negatif, mengatasi permasalahan serta untuk menunjukkan identitas diri. Anak-anak muda berbelanja banyak produk pakaian yang tidak dibutuhkan, membelanjakan uang lebih banyak dari yang didapatkan serta tahan berbelanja dalam waktu berjam-jam. Mereka cenderung menyesal, cemas, malu, rendah diri, kurang berfokus pada kuliah dan memiliki hutang.

Program studi eksakta adalah program studi rumpun ilmu pasti yang identik dengan ilmu alam. Objek yang dipelajari oleh ilmu eksakta adalah benda alam dengan hukum yang pasti dan juga umum, hukum ini berlaku kapan saja dan di mana saja. Sedangkan Program studi non eksak merupakan rumpun ilmu yang lebih condong ke berbagai teori dan kurang terdapat perhitungan-perhitungan angka di dalamnya.

Metode pengumpul data pada penelitian ini adalah skala. Ada 2 skala yang digunakan dalam penelitian ini yaitu, skala belanja kompulsif serta skala approah coping (CRI). Approach coping diukur menggunakan skala Coping Respon Inventory (CRI) yang disusun oleh Moos (2004) sebanyak 48 item. Ada 24 item untuk mengukur approach coping dan ada 14 item untuk mengukur avoidance coping. Hasil uji reliabilitas yang dilakukan oleh Chivaneh (2013) pada mahasiswa di Iran menemukan koefisien reliabilitas sebesar $\alpha=0.73$ (Alfa Cronbach) untuk approach coping respon dengan angka validitas bergerak dari 0.43-0.7I. Adapun koefisien reliabilitas avoidance coping diperoleh sebesar $\alpha=0.75$ (Alfa Cronbach). dengan koefisien validitas bergerak dari 0.36-0.53. Skala CRI ini disusun dengan format skala Likert degan jawaban sangat sering dilakukan sampai tidak pernah dilakukan. Pada penelitian ini hanya digunakan item-item yang mengungkap approach coping saja.

Skala belanja kompulsif disusun berdasar teori Dittmar (2005). Ada 3 aspek belanja kompulsif yaitu dorongan yang sangat kuat untuk melakukan pembelanjaan, dorongan berbelanja yang sulit dikendalikan dan konsekwensi yang merugikan. Skala ini disusun sebanyak 28 item dengan koefisien reliabilitas sebesar $\alpha=$ 0.902 ; dengan angka vaiditas bergerak dari 0.308 sampai 0.750 .

Penelitian ini dilakukan dengan langkah-langkah sebagai berikut: (I) Penyusunan Proposal. Penelitian ini diawali dengan menyusun rencana penelitian. Melakukan analisis permasalahan yang urgent untuk diselesaikan, menentukan variabel penelitian, melakukan kajian teori, serta merumuskan hipotesis penelitian. (2) Adaptasi Skala Penelitian. Setelah variabel ditetapkan dan dilakukan kajian teori, peneliti memilih alat ukur (skala) yang sesuai dengan konsep yang diajukan. (3) Uji Coba Instrumen Penelitian. Setelah skala dipilih karena dianggap relevan dengan variabel yang hendak diukur, maka skala tersebut akan ditry-outkan pada sebagian populasi. (4) Melakukan Penelitian. Setelah instrumen penelitian (skala) telah memenuhi kaidah pengukuran yaitu validitas dan reliabilitas, maka peneliti akan mengambil data di lapangan. (5) Analisis Data Penelitian. Setelah data terkumpul akan dilakukan seleksi, skoring, tabulasi yang kemudian dilakukan analisis data penelitian. 
Metode analisis data yang digunakan pada penelitian ini adalah analisis moderasi (Moderation Analysis) dari Hyes. Metode ini dimaksudkan untuk mengetahui hubungan antara approach coping dengan belanja kompulsif pakaian dan apakah program studi eksakta/non eksakta mampu memoderasi hubungan antara approach coping dengan belanja kompulsif pakaian. Analisis data pada penelitian ini dilakukan dengan bantuan program SPSS v.2I.

\section{Hasil}

Hasil uji hubungan antara approach coping dengan belanja kompulsif pakaian sebagaimana tabel berikut:

Tabel I. Hasil Uji Hubungan Antara Approach Coping Dengan Belanja Kompulsif Pakaian Dengan Program Studi Eksakta dan Non-Eksakta sebagai Variabel Moderator

\begin{tabular}{ccccc}
\hline Model I & Standard Error & t & B & P \\
\hline $\begin{array}{c}\text { Approach Coping- } \\
\text { Belanja Kompulsif }\end{array}$ & 0.1350 & -11.5789 & -1.5632 & 0.000 \\
$\begin{array}{c}\text { Pakaian } \\
\text { Moderasi X dan Y }\end{array}$ & 0.2754 & 4.7331 & 1.3033 & 0.000 \\
\hline
\end{tabular}

Tabel I. menunjukkan bahwa ada hubungan negatif yang sangat signifikan antara approach coping dengan belanja kompulsif pakaian pada mahasiswi yang ditunjukkan dengan $B=-I .5632$, dengan $p=0.000(<0.0 I)$. Artinya, semakin sering anak-anak muda menggunakan approach coping saat dihadapkan pada sebuah persoalan maka semakin rendah kecenderungan mereka untuk melakukan pembelanjaan kompulsif pakaian. Dengan demikian, hipotesis yang menyatakan bahwa ada hubungan negatif antara approach coping dengan belanja kompulsif pakaian, diterima.

Hasil penelitian juga menemukan $B=1.3033$ dengan $p=0.000(p>0.01)$. Hal ini menunjukkan bahwa program studi mampu memperkuat hubungan antara approach coping dengan belanja kompulsif pakaian. Dengan demikian, hipotesis yang menyatakan program studi mampu memoderasi hubungan antara approach coping dengan belanja kompulsif pakaian, diterima.

\section{Pembahasan}

Hasil penelitian menemukan bahwa ada hubungan negatif antara approach coping dengan belanja kompulsif pakaian pada mahasiswi. Semakin sering anak-anak muda menggunakan pendekatan approach coping atau active problem solving ketika dihadapkan pada persoalan kehidupan sehari-hari, maka semakin rendah kecenderungan mereka melakukan pembelanjaan kompulsif pakaian. Semakin jarang mereka menggunakan pendekatan approach coping atau active problem solving ketika dihadapkan pada persoalan sehari-hari, maka semakin tinggi kecenderungan mereka melakukan pembelanjaan kompulsif pakaian.

Hasil penelitian ini mendukung temuan penelitian Otero-Lopes dan Villardefracos (20l4) bahwa active problem solving atau approach coping yang telah terpola dalam kehidupan individu mampu menjadi faktor yang dapat memproteksi untuk melakukan pembelanjaan kompulsif. Active problem solving atau approach coping mampu membantu individu mengelola pikiran-pikiran tentang pembelanjaan (obsessive) yang hadir terus menerus, keinginan dan melakukan pembelanjaan secara kompulsif. Ketika individu dihadapkan pada banyaknya iklan produk atau jasa, baik di media sosial, TV, papan reklame, majalah, dll. individu berusaha mengamati informasi yang ada di iklan dengan lebih detail. Ketika individu tertarik dengan produk atau jasa yang diiklankan, individu akan mencari informasi yang relevan dari berbagai sumber, mengevaluasi informasi dengan cermat, mempertimbangkan banyak hal sebelum melakukan pembelanjaan dan mengambil keputusan pembelanjaan (Schiffman, Kanuk, \& Wisenblit, 20I0).

Billieux, et al., (2008) mengemukakan bahwa individu yang memiliki kecenderungan belanja kompulsif tinggi mengalami hambatan dalam proses berpikir saat melakukan pembelanjaan dan sangat didominasi oleh emosi negatif. Kurang berfungsinya proses berpikir yang dimiliki individu mengakibatkan rendahnya kemampuan untuk memperhitungkan konsekwensi positif dan negatif dari pembelanjaan yang dilakukannya. Pengambilan 
keputusan yang dilakukan lebih mendasarkan pada respon emosional. Rendahnya kemampuan pengambilan keputusan ini berpotensi untuk menghasilkan pembelanjaan negatif jangka panjang terutama resiko finansial.

Cara individu merespon stimulus pemasaran dengan menggunakan proses berpikir logis dapat menghasilkan perilaku berbelanja yang wajar atau tidak berlebih. Individu yang menerima stimulus pemasaran akan melihatlihat, membanding-bandingkan, mengevaluasi secara mendalam dan memutuskan untuk melakukan pembelian atau tidak. Individu akan mengevaluasi kembali setelah melakukan pembelian, produk atau jasa yang telah dibeli sesuai dengan kebutuhan atau tidak dan dapat memuaskan kebutuhannya ataukah tidak (Otero-Lopes dan Villardefracos (2014). Individu yang memiliki kecenderungan melakukan pembelanjaan kompulsif tinggi memiliki isi pikiran yang keliru tentang pembelanjaan kompulsif yang dilakukan dan pembelanjaaan kompulsif yang dilakukannya menjadi reward untuk dirinya sendiri (self-reinforcing) dari waktu ke waktu. Pemikiran yang keliru tentang belanja inilah yang menjadikan individu melakukan pembelanjaan kompulsif (Kellett, \& Bolton, 2009).

Hasil penelitian juga menunjukkaan bahwa program studi mampu memoderasi hubungan antara approach coping dengan belanja kompulsif pakaian. Program studi eksakta dan non eksakta mampu memperkuat hubungan antara approach coping dengan belanja kompulsif pakaian. Mahasiswi yang belajar pada program studi eksakta mempelajari benda alam dengan hukum yang pasti dan juga umum. Aktivitas perkuliahan mereka lebih banyak melibatkan proses berpikir analisa, berpikir praktis dan berpikir kompleks dibanding dengan mahasiswa yang kuliah pada program studi non-eksakta. Tuntutan aktivitas perkuliahan ini akan membentuk pola pikir, pola merasakan serta pola berperilaku pada mahasiswa. Perbedaan aktivitas diperkuliahan ini berpengaruh pada proses pembelanjaan yang dilakukannya (Udo-Imeh, 20I5).

\section{Kesimpulan}

Hasil penelitian menemukan bahwa ada hubungan negatif antara approach coping dengan belanja kompulsif pakaian pada mahasiswi. Anak-anak muda yang sering menggunakan approach coping dalam menghadapi persoalan sehari-hari akan memiliki kecenderung belanja kompulsif rendah. Namun anak-anak muda yang jarang menggunakan approach coping dalam menghadapi persoalan hidup sehari-hari cenderung melakukan pembelanjaan kompulsif pakaian tinggi. Program studi eksakta dan non-eksakta mampu memperkuat hubungan antara approach coping dengan belanja kompulsif pakaian pada mahasiswi.

Mahasiswa dapat melatih diri untuk melakukan approach coping atau active coping atau problem solving dengan cara belajar menyelesaikan persoalan-persoalan yang dialami. Pendekatan approach coping ini lama-lama akan terbentuk atau terpola dalam diri dan menjadi habit dan akan muncul secara otomatis ketika dihadapkan pada persoalan-persoalan kehidupan yang lain, misalnya perilaku berbelanja. Peneliti yang tertarik meneliti tentang approach coping dengan belanja kompulsif pakaian dapat menggunakan kognitif-afektif-behavior dalam membahas tentang belanja kompulsif pakaian.

\section{REFERENSI}

Aghdar, A. (2016). Analyzing the relationship between coping responses and metacognitive beliefs with addiction potential among male and female students (case study: medical science university of behbahan, iran). International Journal of Humanities and Cultural Studies, 3 (I), II5-I27. ISSN 23565926. http://www.ijhcs.com/index

Chivaneh, M. (20/3). The examination of reliability and validity of coping responses inventory among Iranian students. 3rd World Conference on Psychology, Counselling and Guidance (WCPCG-20I2). Procedia - Social and Behavioral Sciences 84, 607-614

Dittmar, H. (2004). Are you what you have? consumer society. The Psychologist, I7 (4), p. 206-2II.

Dittmar, H. (2005). Compulsive buying - a growing concern? An examination of gender, age, and endorsement of materialistic values as predictors. British Journal of Psychology, 96, p. 467-49I. Doi: I0.1348/0007/2605×535333

Dittmar, H., Long, K. \& Bond, R. (2007). When a better self is only a button click away: associations between materialistic values, emotional and identity-related buying motives, and compulsive buying 
tendency online. Journal of Social and Clinical Psychology, 26 (3), 334-36I. Doi: I0.152I/jscp.2007.26.3.334

Benson, A.L., Dittmar, H.E. \& Wolfsohn, R. (2010). Compulsive buying: cultural Contributors and consequences in impulse control disorders: a clinical guide. London: Cambridge University Press.

Djudiyah. (2018). Avoidance coping memediasi hubungan antara contingent self-esteem dengan belanja kompulsif pakaian. Laporan Penelitian. Malang: DPPM Universitas Muhammadiyah Malang.

Dziurzyńska, E., Pawłowska, B. \& Potembska, E. (2016). Coping strategies in individuals at risk and not at risk of mobile phone addiction. Curr Probl Psychiatry, 17(4), 250-260. Doi: 10.15I5/cpp-2016-0024

Filomensky, T. Z. \& Tavares, H. (2009). Cognitive restructuring for compulsive buying. Rev Bras Psiquiatr, $3 I(I), 76-8 I$.

Flórez, L. E. G., Escobar, M. I. C., Restrepo, A. H., Botero, D. A., \& Arias, A. V. (2017). Influence of social networks on the purchase decisions of university students. Cuadernos de Gestión, I8 (I) , 6I-84. Doi: 10.5295/cdg.| 50577 lj

Gupta, R., Derevensky, J. \& Marget, N. (2004). Coping strategies employed by adolescents with gambling problems. Child and Adolescent Mental Health, 9(3), II5-I 20.

Günüç, S. \& Keskin, A. D. (2016). Online shopping addiction: symptoms, causes and effects. Addicta: The Turkish Journal on Addictions, 3, 353-364. http://dx.doi.org/10.15805/addicta.2016.3.0104

Kellett, S., \& Bolton, J.V. (2009). Compulsive buying: a cognitive-behavioural model. Clin Psychol Psychother, 16 (2), 83-99.. Doi: 10.1002/cpp.585

Lazarus, R. S. (1993). Coping theory and research: past, present and future. Psychosomatic Medicine, 55, 234247.

Moos, R. H. (2004). Coping responses inventory: an update on research applications and validity. Odessa. FL: Psychological Assessment Resources.

O'Reilly, C. (2016). The effect of social media and compulsive behavior on younger and older adults. Department of Social Science. DBS School of Arts. Dublin.

Otero-Lopes, J. M. \& Villardefracos, C. (20I4). Prevalence, sociodemographic factors, psychological distress, and coping strategies related to compulsive buying: a cross sectional study in Galicia, Spain. BMC Psychiatry, I4, I-I2. Doi:I0I|86/|47|-244x-|4-101

Schiffman, L.G. , Kanuk, L.L. \& Wisenblit, J. ( 2010). Consumer behavior. Tenth Edition. New Jersey : Prentice Hall International, Inc.

Servidio, R., Gentile, A., \& Boca, S. (2018). The mediational role of coping strategies in the relationship betweenself-esteem and risk of internet addiction. Europe's Journal of Psychology, 14(I), I76-187. Doi: 10.5964 /ejop.v|4il.| 449

Udo-Imeh, P.T. (2015). Influence of personality on the buying behaviour of undergraduate Students in universities in cross river state, Nigeria. International Journal of Marketing Studies, 7(4), 64-77. Doi: 10.5539/ijms.v7n4p64

Ureta, I. G. (2007). Addictive buying: causes, processes and symbolic meanings. Thematic analysis of a buying addict's diary. The Spanish Journal of Psychology, 10(2), 408-422 